\title{
RAC3 Gene
}

National Cancer Institute

\section{Source}

National Cancer Institute. RAC3 Gene. NCI Thesaurus. Code C104817.

This gene is involved in both cytoskeletal remodeling and GT Pase activity. 